\title{
AN UNTIMELY COMPLETION
}

\author{
Christopher Fox
}

I'm writing these words about my great friend Bob Gilmore, four weeks after getting the news that he had died. Since then I have been to Amsterdam to his funeral, a wonderful occasion suffused with love, planned and realised with the most extraordinary care by Bob's partner, Elisabeth Smalt, and his son, Ben. I have thought about all the times Bob and I ate, drank, strolled, talked, worked together, I have re-read our email correspondence, listened to recordings of him playing and talking, and still part of me - quite a large part - cannot reconcile myself to the idea that there will be no more from this astonishing man.

So what follows is necessarily partial - just a few words to describe someone who brought such energy to so many activities - and still tinged with this disbelief. But I think Bob would have understood. Everything about the way he lived the last two years of his life after the cancer diagnosis suggests that he too could not quite believe that one day he would be stopped in his tracks. This is not to suggest that he was in any sort of denial about his condition; on the contrary, he knew he was dying but, because he did not want this to become the subject of his life, he lived as if he were not.

Bob also understood that great lives leave the rest of us with memories, and perhaps a body of work too, which can sustain us long after the person who created them has gone. I remember sitting with Bob in the living room at the top of the house that he and Elisabeth made their home in the Hazenstraat, listening to recordings, looking at scores, gazing across the rooftops and trees, talking about music. Bob talked about music with the sort of passion that always marks out people for whom music is like breath, like food, like sunlight, utterly indispensible. And because Bob loved people he moved easily between talk about music and talk about the people who made it.

This in turn informed the sort of work he did. His reputation as a musicologist will surely rest on his biographies of Harry Partch and Claude Vivier, works which have both the magisterial authority that comes from painstaking research and the accessibility of the story well told. In both books Bob scrupulously delineates what he knows and what he can only speculate about, but he tells stories too, and it's his ability to do this that distinguishes these books from most musical scholarship. Through their pages we get to know Partch and Vivier as people and to understand what it was about them that made them write music; in turn we discover why this music is so remarkable and why, by making it, these troubled, awkward people became so fascinating that we need to read about them. It sounds straightforward but it's only in the hands of a master like Bob that the constant transition - life and works, works and life becomes so seamless that we barely notice it.

I knew of Bob long before we became friends. We were students at York University at the same time, he an undergraduate, I a doctoral student whose registration was beginning to stretch. I knew him by 
sight - a cap, reminiscent of the one Bob Dylan wore on the cover of his first LP, was usually perched on top of Bob's wildly curly hair but we never talked. Years later I reviewed his Harry Partch book for Musical Times and then invited him to write for a Contemporary Music Review issue on 'Microtones and Microtonalities'. He responded, not only with a characteristically brilliant synoptic article, 'The climate since Harry Partch', but also with a Radulescu interview.

The pace picked up: we examined a doctoral student together at Dartington College, where he had taught for many years and where I suspect he had his most satisfactory teaching experiences, and I asked him to be an external consultant to review the new degree course we were developing at Brunel University. He liked what we were doing and when the prospects for Dartington's survival began to look ominous he came to join us, commuting from Amsterdam and taking up weekly residence either on campus or in deepest Surrey with his old York University friend, James Poke. He and I taught musicology together and sat in on one another's classes, partly to comply with the university's requirement for 'peer observation of teaching' but more because it was interesting. There was no higher approval than Bob's 'very good, very good, very good', rattled out at speed, like a polka, the same upward inflection on each repetition.

Bob loved teaching and the students loved him. His enthusiasm made things happen which the rest of us had begun to doubt were possible within the formal structures of the university. He introduced extra classes, outside the timetable, to encourage the students to develop their analytical, research and writing skills. He formed ensembles with students, playing alongside them in performances of early Glass and Bryars, took a group of students to Amsterdam to be part of a production of Noyes Fludde and, most memorably, put together a project with Phill Niblock in which an ensemble of staff and students worked with the composer on recordings and a concert in Café Oto.

As well as his writing and teaching Bob had a remarkable, laterblooming, performing career, centred on Trio Scordatura and inspired by his love for Elisabeth Smalt. I had the good fortune to benefit from this too. In 2007 he asked me to write for the Trio and in 2008 they premiered my fur Johannes Kepler. One thing led to another and two summers later we gathered in James Poke's home and studio to make a CD, Natural Science. In the last year of Bob's life we were talking about more projects. What made Bob such a good musician was not just his technical facility as a keyboard player - he was really good - or his capacity to operate in so many different arcane tuning systems - his hearing was uncannily accurate - but his ability to balance his innate enthusiasm for whatever he was doing with a fierce critical intelligence. Mostly things went well but when they didn't they were 'shite'.

With a life so full it's difficult to know where to stop, particularly when I know that by going on I can stay in Bob's company a little longer. Donnacha Dennehy had it about right when he said that Bob's death robbed us not only of a true friend but of the best listener we composers could ever wish for. So it seems appropriate to close with a few Bob-isms, remarks from emails written in Bob's unique concoction of different vernaculars, from Ulster to P.G. Wodehouse to street, to remind me of the man we have lost.

I suggested that the Trio Scordatura CD should include Bob reading the Ian Duhig poems that are part of my Natural Science. Bob replied: 'what I say to that idea is: SUPER. I like his poems immensely. I say: GO FOR IT. Elisabeth (by the way) mentioned, in a totally 
Zen-like and non-confrontational way, that she thinks the CD should be just the Trio, and no guests. I also can see the appeal of that, and yet my Irish soul is always happy to be surrounded by other people, indeed the more the merrier.' (23 March, 2010).

He sent me the typescript of the Vivier book and I wrote to say how impressive I found it. '.. and right back at ye, dear C, as today I finally managed to listen to the recording of your absolutely wonderful and deeply moving opera. What a marvellous piece!' $\left(24^{\text {th }}\right.$ January 2013)

In 2014 an expanded version of the Trio recorded my qui/nt/et. 'We had a great time last night massacring your fine qui/nt/et. We rehearse and record today. In that order. Otherwise, spiffing piece! Will hopefully make it sound tasty.' (24 ${ }^{\text {th }}$ February 2014)

Our last collaboration was a new project for the Trio, for which Bob invited composers to write music based on madrigals by Nicola Vicentino (1511-75), using his fifth-tone tuning system. 'Dear Christoph Le Maître, we love your fantastic little Vicentino piece so much that we've added it to our concert in Amsterdam on October 31st. [...] We are taking it quite a bit below the specified metronome mark (gulp) because it sounds so YUMMY a bit slower. Just so's you know.' (26 $6^{\text {th }}$ September 2014)

And still full of plans: 'Dearest C, very best of luck for the performance in 'udds this week. So wish I could hear it! Am finally getting in gear with the new Gilmore book, more on which anon. Let us hope the stars are favourable to its timely completion, etc etc.' $\left(23^{\text {rd }}\right.$ November 2014)

30 January 2015 